\title{
Efficacy of training of maternal behavior on mother's parenting stress
}

\author{
Somayeh Bazargan $^{\mathbf{a}^{*}}$, Yousef Gorji ${ }^{\mathrm{b}}$ and Mohammad Reza Abedi ${ }^{\mathrm{c}}$
}

${ }^{a}$ M.A on Counseling, Department of Counseling, Khomeinishahr Branch, Islamic Azad University, Khomeinishar, Iran

${ }^{b}$ Assistant Professor, Department of Counseling, Khomeinaishahr Branch, Islamic Azad University, Khomeinishahr, Iran ${ }^{c}$ Associate Professor, Department of Counseling, University of Isfahan, Isfahan, Iran

\section{H R O N I C L E A B S T R A C T}

Article history:

Received October 28, 2012

Received in revised format

18 February 2013

Accepted 19 February 2013

Available online

February 252013

Keywords:

Maternal behavior

Abidin parenting stress

questionnaire

Training programs
This paper performs a study to find the effect of training maternal behavior on a group of mothers who live in city of Esfahan, Iran. The study divides them into two experimental group and control group and examines the effects of training programs. The sample includes 40 women who have, at least, one child aged 4-8 years. The survey uses Abidin parenting stress questionnaire [Abidin, R. R. (1995). Parenting Stress Index. Odessa, FL: Psychological Assessment Resources.] and one group goes under 8 sessions of 2 hours long training programs. The results of ANOVA test indicate that two groups of mothers behave differently after attending training programs when the level of significance is one percent.

\section{Introduction}

There has been a growing concern among different societies on learning the effects of having better childcare on quality of life (Chilman, 1980; Guralnick, 2005). Bolger and Patterson (2001) implemented a prospective longitudinal design and examined rejection by peers, aggressive behavior, and social withdrawal for a sample of 107 maltreated children and an equal number of nonmaltreated ones. They reported that chronic maltreatment was positively related to heightened risk of rejection by peers. They also stated that chronically maltreated children were more likely to be rejected by peers repeatedly across different years from childhood to early adolescence.

According to Deater-Deckard and Scarr (1996), stress in the parenting role is associated with family functioning and parenting behavior. They performed an investigation on 589 married couples with young children (12 to 60 months old) completed the Parenting Stress Index-Short Form (Abidin, 1990) and measured of child-rearing behaviors and attitudes, social support, and child behavior. They

Corresponding author. Tel: +989133216535

E-mail: somayeh.bazargan@iaukhsh.ac.ir(S. Bazargan)

(C) 2013 Growing Science Ltd. All rights reserved. doi: 10.5267/j.msl.2013.02.023 
reported small effects for mothers and fathers, which were moderated by child age and marital happiness. Putnick et al. (2010) studied how parenting stress could possibly attribute to the parent or the child by comparing mothers and fathers from the same families in terms of parenting stress and examined how one parent's stress influenced the other parent's stress. They reported that mothers' and fathers' increased parenting stress across their child's transition to adolescence seemed to derive from parent-child interaction rather than qualities of the parent or the child per se.

Dunst (1999) argued that although parent education needs to be reemphasized and parent education should not be a more explicit focus of current early-intervention efforts. Floyd and Phillippe (1993) compared the in-home interactions of parents with their school-age children among 53 different families of children with mild or moderate mental retardation (MNR) with 51 families of children without MNR aged 6-18. They reported that the parents of children with MNR were more controlling and less playful with their children but they presented effective behavior management practices without resorting to coercive control strategies.

Mahoney (2009) investigated the relationship between parenting stress and mother-childinteraction style among some mothers of children with pervasive developmental disorders (PDD) and developmental disabilities (DD). The sample included the people who took part in a Relationship Focused (RF) intervention in about one year. They analyzed some relationships between children's diagnoses, severity, parenting stress, and mother-child interaction style. They investigated some correlation and hierarchical regression statistical procedures with two groups of mothers of 44 children, ages 11-54 months who filled pre and post treatment group only. The reported that mothers of children with PDD experienced more parenting stress than mothers of children with DD. In addition, the severity of children's disabilities was a substantial predictor of the level of parenting stress mothers reported.

In this paper, we perform an empirical investigation to study the effect of training maternal behavior on a group of mothers who live in city of Esfahan, Iran. The organization of this paper first presents details of the proposed model in section 2 while section 3 explains the results and concluding remarks are given in the last to summarize the contribution of the paper.

\section{The proposed model}

This paper performs a study to find the effect of training maternal behavior on a group of mothers who live in city of Esfahan, Iran. The study divides them into two experimental and control groups and examines the effects of training programs. The sample includes 40 women who have, at least, one child aged 4-8 years. The survey uses Abidin parenting stress questionnaire (Abidin, 1995) and one group goes under 8 sessions of 2 hours long training programs. The proposed study of this paper considers the following hypothesis,

Training maternal behavior on mother’s parenting stress influences children's realm.

Table 1 shows some of the basic statistics associated with the proposed study of this paper.

\section{Table 1}

The summary of basic statistics on parenting stress (Number of observation $=15$ )

\begin{tabular}{lccccc}
\hline Stage & Group & Mean & Standard deviation & Min & Max \\
\hline Pre-test & Experiment & 116.6 & 29.13 & 70 & 152 \\
& Control & 122.8 & 29.8 & 78 & 154 \\
\hline \multirow{2}{*}{ Post-test } & Experiment & 115.2 & 28.72 & 70 & 152 \\
& Control & 123.8 & 19.7 & 78 & 153 \\
\hline \multirow{2}{*}{ Follow up } & Experiment & 113.6 & 28.21 & 70 & 150 \\
& Control & 123.9 & 21.1 & 75 & 159 \\
\hline
\end{tabular}


As we can observe from the results of Table 1, the mean of pre-test is reduced after experiment is executed.

\section{The results}

In order to examine the effect of the training programs, we have used ANOVA test to examine the difference between pretest and posttest and Table 2 demonstrates the results of our survey.

\section{Table 2}

The summary of ANOVA test

\begin{tabular}{llllllll}
\hline $\begin{array}{l}\text { Source of } \\
\text { changes }\end{array}$ & $\begin{array}{l}\text { Sum of } \\
\text { Squares }\end{array}$ & df & $\begin{array}{l}\text { Mean of } \\
\text { squares }\end{array}$ & F & P-Value & eta & $\begin{array}{l}\text { Statistical } \\
\text { power }\end{array}$ \\
\hline test & 60.35 & 2 & 30.17 & 12.44 & 0.001 & 0.31 & 0.90 \\
\hline
\end{tabular}

The results of ANOVA test indicates that there is a meaningful difference between two groups of experiment and control after performing the test when the level of significance is one percent. In other words, the test has shown to be promising to reduce the parenting stress. We have also performed LSD test in three regions of pretest, posttest and follow up to see the effects of training program and Table 3 demonstrates the results of our experiments.

\section{Table 3}

The summary of LSD test

\begin{tabular}{lccc}
\hline Experiment & Mean difference & Standard deviation & P-Value \\
\hline Pretest-Posttest & 8.73 & 1.3 & 0.001 \\
Pretest-Follow up & 13.2 & 2.1 & 0.001 \\
Posttest-Follow up & 4.46 & 1.46 & 0.009 \\
\hline
\end{tabular}

The results of Table 3 demonstrates that training maternal behavior will reduces the causes of parenting stress in mothers in children's lives.

\section{Conclusion}

The results of this survey have shown that maternal parenting stress reduction training will effectively influence on maternal behavior to help children reduce their stress building a better confidence with their parents. This could allow the children to explore the environment and to communicate with their parents more efficiently. In other words, the principle of double parental behavior affects children and parents can influence children's behavior. This is in accordance with Belsky and Fearon (2008) results, changes in maternal behavior and ultimately change the child's behavior are complex factors. The results of our survey are also consistent with Benzies (2004) who did investigation on parenting stress, marital quality, and child behavior problems at age 7 years.

\section{Acknowledgment}

The authors would like to thank the anonymous referees for constructive comments on earlier version of this paper.

\section{References}

Abidin, R. R. (1995). Parenting Stress Index. Odessa, FL: Psychological Assessment Resources. Belsky, J., \& Fearon, R. M. (2008). Precursors of attachment security. In: Cassidy, J., Shaver, P. R.eds. Handbook of attachment: theory, research, and clinical applications. New York, NY: Guilford Press; 295-316. 
Benzies, K. M., Harrison, M. J., \& Magill-Evans, J. (2004). Parenting stress, marital quality, and child behavior problems at age 7 years. Public Health Nursing, 21(2), 111-121.

Bolger, K. E., \& Patterson, C. J. (2001). Developmental pathways from child maltreatment to peer rejection. Child Development, 72(2), 549-568.

Chilman, C. S. (1980). Parent satisfactions, concerns, and goals for their children. Family Relations, 339-345.

Deater-Deckard, K., \& Scarr, S. (1996). Parenting stress among dual-earner mothers and fathers: Are there gender differences?. Journal of Family Psychology, 10(1), 45.

Dunst, C. J. (1999). Placing parent education in conceptual and empirical context. Topics in Early Childhood Special Education, 19(3), 141-47.

Floyd, F. J., \& Phillippe, K. A. (1993). Parental interactions with children with and without mental retardation: Behavior management, coerciveness, and positive exchange. American Journal on Mental Retardation, American Journal on Mental Retardation, 97(6), 673-684.

Guralnick, M. J. (2005). An overview of the developmental systems model for early intervention. The developmental systems approach to early intervention, 3-28.

Mahoney, F. P. (2009). The Relationship between Parenting Stress and Maternal Responsiveness among Mothers of Children with Developmental Problems (Doctoral dissertation, Case Western Reserve University).

Putnick, D. L., Bornstein, M. H., Hendricks, C., Painter, K. M., Suwalsky, J. T., \& Collins, W. A. (2010). Stability, Continuity, and Similarity of Parenting Stress in European American Mothers and Fathers Across Their Child's Transition to Adolescence. Parenting: Science and Practice, 10(1), 60-77. 